\title{
Platelet-derived growth factor-BB (PDGF-BB) improves follicular survival, oocyte and follicular diameters, in a dose-dependent manner, after the in vitro culture of goat preantral follicles enclosed in ovarian tissue fragments
}

\author{
Renato Félix da Silva ${ }^{1,4}$, Ivina Rocha Brito ${ }^{1}$, Laritza Ferreira de Lima ${ }^{1}$, Francisco Léo Nascimento de \\ Aguiar $^{1}$, Giovanna Quintino Rodrigues ${ }^{1}$, Ivila Lorrine Castro do Nascimento ${ }^{1}$, Rebeca Magalhães Pedrosa \\ Rocha $^{1}$, Francielli Weber Santos Cibin ${ }^{2}$, Matthew Bryan Wheeler ${ }^{3}$, Claudio Cabral Campello ${ }^{1}$, \\ Ana Paula Ribeiro Rodrigues ${ }^{1}$, José Ricardo de Figueiredo ${ }^{1}$ \\ ${ }^{1}$ Laboratory of Manipulation of Oocytes and Preantral Follicles, Faculty of Veterinary, State University of Ceara, Itaperi \\ Campus, Fortaleza, CE, Brazil. \\ ${ }^{2}$ Federal University of Pampa, Uruguaiana, Rio Grande do Sul, Brazil. \\ ${ }^{3}$ Department of Animal Sciences, University of Illinois, Urbana-Champaign, Urbana, IL, USA.
}

\begin{abstract}
The aims of this study were to investigate the effects of different concentrations of Platelet-derived growth factor-BB (PDGF-BB) on the survival, activation, levels of ROS, and growth of goat preantral follicles enclosed in ovarian tissue. For this, ovarian fragments were cultured for 7 days in Alpha Minimum Essential Medium $\left(\alpha-\mathrm{MEM}^{+}\right)$with or without PDGF-BB $(0,25,50$ and $100 \mathrm{ng} / \mathrm{ml})$. The results showed that both the $25 \mathrm{ng} / \mathrm{ml}$ PDGF and the $50 \mathrm{ng} / \mathrm{ml}$ PDGF treatments maintained the percentage of morphologically normal follicles from day 1 to day 7 . In addition, the $25 \mathrm{ng} / \mathrm{ml}$ PDGF treatment showed a significantly higher percentage of morphologically normal follicles when compared to the other treatments. At day 7 , greater $(\mathrm{P}<0.05)$ follicular and oocyte diameters were observed in the $25 \mathrm{ng} / \mathrm{ml}$ PDGF and the $50 \mathrm{ng} / \mathrm{ml}$ PDGF treatments when compared to the cultured control treatment. On day 7 of culture, all the treatments tested had a significant increase in the percentage of developing follicles when compared to the non-cultured control. However, the percentage of follicle activation, as well as ROS production, were similar $(\mathrm{P}<0.05)$ among the treatments, irrespective of culture time. In conclusion, PDGF-BB improved, in a concentration-dependent manner, follicular survival as well as oocyte and follicular diameter after in vitro culture of goat preantral follicle-enclosed in ovarian tissue fragments.
\end{abstract}

Keywords: goat, in vitro culture, PDGF-BB, preantral follicles.

\section{Introduction}

Folliculogenesis is defined as the formation of primordial follicles, their recruitment into the growing pool, and their further progression to the preovulatory stage in the ovary (Oktem and Oktay, 2008). In this process, proper metabolic bidirectional communication among the oocyte and somatic cells inside the follicle is crucial to control the follicular fate (Van Den Hurk and Zhao, 2005). Understanding the signals responsible for the initiation of folliculogenesis is an important step towards developing a successful in vitro culture system (Chaves et al., 2010). Thus, to achieve this goal, preantral follicles have been cultured in different in vitro culture systems, i.e., isolated form (Brito et al., 2014) or enclosed in ovarian tissue (in situ form; Bruno et al., 2009).

The in vitro culture of isolated follicles of farm animals aims to study mainly late preantral folliculogenesis, including the development of advanced secondary follicles to tertiary follicles (antral follicles). On the other hand, in situ culture of preantral follicles is an effective approach to study factors implicated in the regulation of early follicular development (primordial, intermediate, primary and early secondary stages). Among these factors, platelet-derived growth factor (PDGF) can be highlighted. PDGF is a dimeric glycoprotein composed of four different polypeptide chains, which can be linked by disulphide bonds in various combinations of two to five isoforms, as follows: PDGF-AA, -BB, -AB, -CC, and -DD (Rubin et al., 1988; Young et al., 1990; Berridge, 1993; Gaultier and Michel, 1999).

Several studies have shown that different PDGF isoforms, in a concentration-dependent manner, stimulate follicular activation (transition from primordial to developing follicles, when surrounding squamous pre-granulosa cells become cuboidal and begin to proliferate and grow; Fortune et al., 2000; Fortune, 2003; McLaughlin and Mclver, 2008; Kim, 2012) as well as the proliferation of granulosa and theca cells (rats: Duleba et al., 1999; Nilsson et al., 2006; humans: Hwu et al., 2009). In goats, our team demonstrated that PDGF-B increased follicular growth and antrum formation rates of isolated advanced secondary follicles in a concentration-dependent manner (Brito et al., 2012). Furthermore, it was verified in this species that there was the expression of PDGF-BB mRNA and protein in the early preantral and antral follicles (Brito et al., 2015). Despite the encouraging results achieved in goats using isolated secondary follicles in an advanced stage of development, the originality of the present work is based on the lack of information about the effect of PDGF-BB on early folliculogenesis, i.e., the culture of early preantral follicles (primordial, intermediate, and primary). This study is justified by the fact that follicular requirements vary according to the developmental stage. To date, the pattern of gene expression has been analyzed in goats in the transition from secondary to early tertiary follicles,

${ }^{4}$ Corresponding author: jrf.lamofopapapers@gmail.com

Phone: +55(85)3101-9852; Fax: +55(85)3101-9840

Received: December 12, 2016

Accepted: July 12, 2017 
and that analysis showed that there were $\sim 2,466$ genes specific only to this stage of development (MagalhãesPadilha et al., 2013).

Reactive oxygen species (ROS) are produced in metabolic and physiological cellular process. However, under certain conditions (i.e. in vitro culture), an imbalance in the ROS production may occur, which can jeopardize the survivability and development of these follicles in vitro (Talebi et al., 2012). Moreover, some studies have been investigating ROS production as an additional parameter of the in vitro culture's efficiency (Aguiar et al., 2016a, b; 2017; Paes et al., 2016). In fact, our research group has been measuring ROS levels in some articles (Carvalho et al., 2014; Castro et al., 2014; Sá et al., 2017) throughout the entire period of culture with the goal to demonstrate the efficacy of in vitro culture.

Therefore, to understand the effect of PDGF$\mathrm{BB}$ on early folliculogenesis in goats better, the aim of this study was to investigate the effects of different concentrations of PDGF-BB on the survival, activation, growth, and levels of ROS of preantral follicles enclosed in ovarian tissue fragments.

\section{Material and Methods}

\section{Chemicals}

Recombinant human PDGF-BB, culture media, and other chemicals used in this study were purchased from Sigma Chemical Co. (St Louis, MO, USA) unless mentioned otherwise.

\section{Source of ovaries}

Ovaries $(\mathrm{n}=10)$ from 5 adult ( 1 to 3 years old $)$, non-pregnant, mixed-breed goats (Capra hircus) were collected at a local slaughterhouse. Immediately postmortem, the ovaries were washed in $70 \%$ alcohol for $10 \mathrm{sec}$ and then 2 times in minimum essential medium (MEM) supplemented with $100 \mu \mathrm{g} / \mathrm{ml}$ penicillin and $100 \mu \mathrm{g} / \mathrm{ml}$ streptomycin. Pairs of ovaries were transported within $1 \mathrm{~h}$ to the laboratory in MEM at $4^{\circ} \mathrm{C}$ (Chaves et al., 2008).

\section{In vitro culture of ovarian tissue}

In the laboratory, the ovaries from each animal were stripped of surrounding fat tissue and ligaments. The ovarian cortex of each pair of ovaries was then divided into 18 slices measuring approximately $3 \times 3$ $\mathrm{mm}$ and $1 \mathrm{~mm}$ thick using a needle and scalpel under sterile conditions. For each animal, two slices of tissue were randomly selected and immediately fixed for histological examination (non-cultured control: day 0). The remaining slices of ovarian cortex (17 slices) were placed individually in 24-well culture dishes, each well containing $1 \mathrm{ml}$ of culture medium. The basic medium (cultured control), referred to as $\alpha-\mathrm{MEM}^{+}$, consisted of $\alpha$-MEM supplemented with $10 \mu \mathrm{g} / \mathrm{ml}$ insulin, $5.5 \mu \mathrm{g} / \mathrm{ml}$ transferrin, and $5 \mathrm{ng} / \mathrm{ml}$ selenium, $2 \mathrm{mM}$ glutamine, 2 $\mathrm{mM}$ hypoxanthine, and $1.25 \mathrm{mg} / \mathrm{ml}$ BSA. The ovarian cortex slices were cultured for 1 or 7 days at $39^{\circ} \mathrm{C}$ in humidified air with $5 \% \mathrm{CO}_{2}$.

\section{Experimental design}

For the experimental conditions, the base medium $\left(\alpha-\mathrm{MEM}^{+}\right)$was supplemented with PDGF-BB at different concentrations, as follow: PDGF $0 \mathrm{ng} / \mathrm{ml}$ (day 1 and day 7), PDGF $25 \mathrm{ng} / \mathrm{ml}$ (day 1 and day 7), PDGF $50 \mathrm{ng} / \mathrm{ml}$ (day 1 and day 7), and PDGF $100 \mathrm{ng} / \mathrm{ml}$ (day 1 and day 7). Each treatment was repeated five times (replicates), and the culture medium was changed every 2 days. The concentrations of PDGF-BB (50 and $100 \mathrm{ng} / \mathrm{ml}$ ) used herein were chosen based on the previous study with the in vitro culture of caprine secondary follicles (Brito et al., 2012). In addition to these concentrations, we also included a lower concentration $(25 \mathrm{ng} / \mathrm{ml})$ of PDGF-BB to provide a concentration curve, which had not yet been established. At the end of each culture time (day 1 and day 7), all treatments were evaluated for morphology, development, and follicular and oocyte diameters. In addition, spent culture media at the end of $24 \mathrm{~h}$ of culture at day 1 and at day 7 of culture (after medium replacement at day 6) were stored at $-80^{\circ} \mathrm{C}$ for ROS analysis.

Morphological analysis and assessment of in vitro follicular growth

Tissues from all treatments (fresh control or cultured for 1 or 7 days) were fixed in $4 \%$ neutral buffered paraformaldehyde for $12 \mathrm{~h}$ and then dehydrated in increasing concentrations of ethanol. After being embedded in paraffin (Synth, São Paulo, Brazil), the caprine tissue pieces were cut into $7 \mu \mathrm{m}$ sections, and every section was mounted on glass slides and stained by periodic acid-Schiff-hematoxylin. The follicle stage and survival were assessed microscopically on serial sections. Coded anonymized slides were then examined by microscopy (Nikon, Sendai, Japan) at 400X magnification.

The developmental stages of follicles have been defined as primordial (oocyte surrounded by a few flattened granulosa cells) or developing, i.e., intermediate (oocyte surrounded by flattened and at least one cuboidal granulosa cell), primary (oocyte surrounded by a complete layer of cuboidal granulosa cells), or secondary (oocyte surrounded by two or more complete layers of cuboidal granulosa cells). These follicles were classified as morphologically normal (follicles containing an intact oocyte and granulosa cells well-organized in layers without a pyknotic nucleus) and degenerated follicles (oocyte with a pyknotic nucleus, retracted cytoplasm, or disorganized granulosa cells detached from the basement membrane), as described by Silva et al. (2004).

Overall, 150 follicles were evaluated for each treatment (30 follicles per treatment in one repetition $\mathrm{x}$ 5 repetitions). To calculate follicular activation and growth, only morphologically normal follicles with a visible oocyte nucleus are recorded, and the proportion of primordial and growing follicles is calculated at day 0 and after day 1 or day 7 of the culture in all treatments. In addition, from the basement membrane, major and minor axes of each normal oocyte and follicle were measured using a light microscope fitted with an eyepiece micrometer (Zeiss, Cologne, Germany) under400X magnification. The average of these two 
measurements was used to determine the diameters of both the oocyte and the follicle.

\section{Assessment of preantral follicle viability by fluorescence microscopy}

Additional pairs of ovaries $(n=3)$ were collected from a slaughterhouse and then cut into fragments at the laboratory. Then, two fragments were immediately processed for follicle isolation (noncultured tissue), and the remaining fragments were cultured for 7 days in basic culture medium $\left(\alpha-\mathrm{MEM}^{+}\right)$ or in the treatment group $(25 \mathrm{ng} / \mathrm{ml}$ PDGF-BB treatment) that provided the best outcome, i.e. a significantly higher percentage of morphologically normal follicles at day 7 of culture when compared with the other treatments. Goat preantral follicles were isolated from ovarian fragments using the mechanical method described by Lucci et al. (1999). Briefly, samples were cut into small pieces with a tissue chopper (The Mickle Laboratory Engineering Co., Gomshal, Surrey, UK) and adjusted to a sectioning interval of $75 \mu \mathrm{m}$. Therefore, samples were placed in MEM supplemented with 3 $\mathrm{mg} / \mathrm{ml} \mathrm{BSA}$ and were suspended 100 times with a large Pasteur pipette (inner diameter, $1600 \mu \mathrm{m})$ and 100 times with a smaller Pasteur pipette (inner diameter, $600 \mu \mathrm{m}$ ) to dissociate the preantral follicles from the stroma. The material obtained was then passed through a $200-\mu \mathrm{m}$ nylon mesh filter. This procedure was performed within $10 \mathrm{~min}$ at room temperature. The viability of the preantral follicles was assessed by the trypan blue dye exclusion test. Briefly, $5 \mathrm{ml}$ of $0.4 \%$ trypan blue (Sigma Chemical Co., St. Louis, MO, USA) was added to $100 \mathrm{ml}$ of isolated and suspended preantral follicles, which were incubated for $1 \mathrm{~min}$ at room temperature. Subsequently, the follicles were examined with an inverted microscope (Nikon, Tokyo, Japan) and classified as nonviable or viable if they were positively or negatively stained with trypan blue, respectively.

\section{Reactive oxygen species (ROS) analysis}

The levels of reactive oxygen species were determined in spent culture media using a spectrofluorometric method (Loetchutinat et al., 2005). For this, culture media from all PDGF-BB-treated groups were incubated with $10 \mu \mathrm{l}$ of 2',7'dihidrodiclorofluorescein diacetate (DCHF-DA; $1 \mathrm{mM}$ ).
The oxidation of DCHF-DA to dichlorofluorescein was measured for the detection of reactive species in the medium. The intensity of fluorescence emission was recorded at $520 \mathrm{~nm}$ (with 480-nm excitation) for $2 \mathrm{~h}$ after the addition of DCHF-DA to the medium.

\section{Statistical analysis}

Data for continuous variables (morphologically normal, primordial, and developing follicles) were initially submitted for Shapiro-Wilk and Bartlett tests to evaluate the normal distribution of the residues and homoscedasticity, respectively. Furthermore, confirming both requirements of the underlying analysis of variance (ANOVA), it was carried out using the GLM procedure of SAS (2002) according to a $4 \times 2$ factorial arrangement of groups, considering the PDGF$\mathrm{BB}$ treatments and time of culture as the main effects. When any main effect or interactions were significant, means were compared accordingly by the StudentNewman-Keuls (SNK) test, whilst Dunnett's test was applied to compare the PDGF-BB-treated groups against the control, with the results expressed as means \pm standard deviation (SD). Ordinarily, data for follicular viability were analyzed as the dispersion of frequency by a chi-square test, and the results were expressed as percentages. In all cases, differences were considered to be significant when $\mathrm{P}<0.05$.

\section{Results}

\section{Effect of PDGF on follicular morphology}

The percentages of morphologically normal preantral follicles (Fig. 1A) in non-cultured control and after 1 or 7 days of culture are shown (Table 1). After 1 day of culture, all treatments resulted in lower $(\mathrm{P}<0.05)$ percentages of morphologically normal follicles than the non-cultured control group except when follicles were cultured in the absence of PDGF $(0 \mathrm{ng} / \mathrm{ml} ; \mathrm{P}>0.05)$. With the progression of the culture period from 1 to 7 days, no change in the percentage of morphologically normal follicles was observed in the $25 \mathrm{ng} / \mathrm{ml}$ PDGF and $50 \mathrm{ng} / \mathrm{ml}$ PDGF treatments ( $\mathrm{P}>0.05)$. In addition, at day 7 the $25 \mathrm{ng} / \mathrm{ml}$ PDGF treatment showed a significantly higher percentage of morphologically normal follicles when compared with the other treatments.
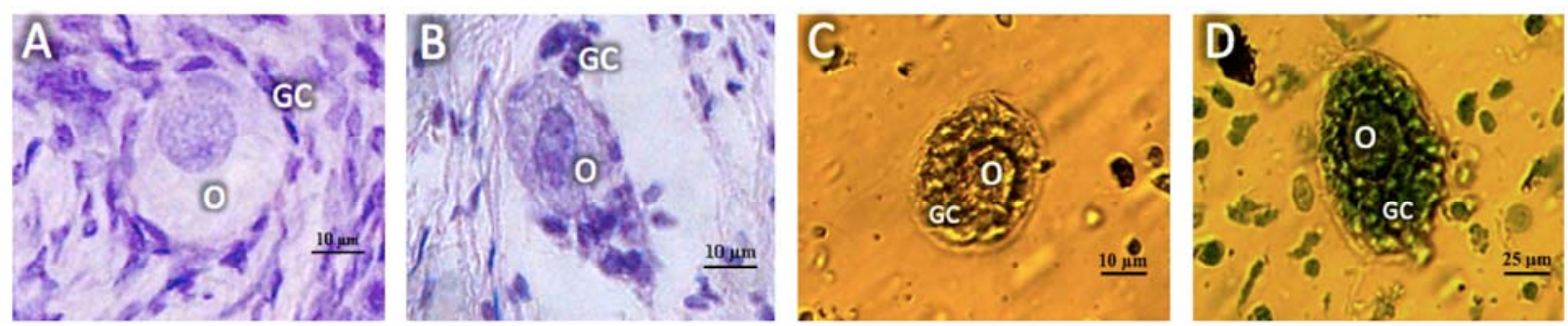

Figure 1. Photomicrographs of preantral follicles analyzed by optical microscopy. Histological sections after staining with periodic acid Schiff-hematoxylin, showing (A) normal preantral follicle and (B) degenerated follicle after culture in control medium (0 ng/ml PDGF-BB) for 7 days. Note the retracted oocyte (B). O: Oocyte; GC: Granulosa cells. Assessment of the viability of preantral follicles using trypan blue stain after culture for 7 days. Viable (C) or nonviable (D) isolated preantral follicle after in vitro culture in control medium (0 ng/ml PDGF-BB). 
Table 1. Percentage of morphologically normal caprine preantral follicles in the fresh control (non-cultured) group and after in vitro culture for 1 or 7 days in the absence or presence of different concentrations of PDGF-BB.

\begin{tabular}{|c|c|c|}
\hline Treatments & \multicolumn{2}{|c|}{ Normal follicles $(\%)$} \\
\hline Control (Day 0) & \multicolumn{2}{|c|}{$82.00 \pm 1.82$} \\
\hline PDGF & Day 1 & Day 7 \\
\hline $0 \mathrm{ng} / \mathrm{mL}$ & $76.67 \pm 4.08^{\mathrm{Aa}}$ & $58.00 \pm 3.80^{*} \mathrm{Bb}$ \\
\hline $25 \mathrm{ng} / \mathrm{mL}$ & $68.67 \pm 1.82^{*} \mathrm{Ab}$ & $65.33 \pm 2.98^{* \mathrm{Aa}}$ \\
\hline $50 \mathrm{ng} / \mathrm{mL}$ & $48.67 \pm 5.05^{* \mathrm{Ad}}$ & $52.67 \pm 4.35^{* \mathrm{Ac}}$ \\
\hline $100 \mathrm{ng} / \mathrm{mL}$ & $56.00 \pm 4.35^{* A c}$ & $48.00 \pm 5.05^{* \mathrm{Bc}}$ \\
\hline
\end{tabular}

*Values differ significantly from fresh non-cultured controls $(\mathrm{P}<0.05) .{ }^{\mathrm{AB}}$ Values with different uppercase superscript letters differ between columns (days) $(\mathrm{P}<0.05) .{ }^{\text {abcd }}$ Values with different lowercase superscript letters differ among rows (treatments) $(\mathrm{P}<0.05)$.

\section{Follicular development after in vitro culture}

The percentages of primordial and developing follicles (intermediate, primary, and secondary) in fresh tissue or in tissues cultured for 1 or 7 days with different treatments are shown (Fig. 2A and 2B). Fresh ovarian tissues predominantly contained primordial follicles $(69.10 \%)$. Under all culture conditions, after 7 days of culture, a significant increase in the percentage of developing follicles was observed compared with the non-cultured control, as well as when compared with day 1 of the culture (Fig. 2B). From day 1 to day 7, in all cultured treatments, a significant decrease was observed in the percentage of primordial follicles with a concomitant increase in the percentage of developing follicles. However, the percentage of developing follicles was similar $(\mathrm{P}>0.05)$ among treatments regardless of the culture time.

\section{A}

Primordial follicle
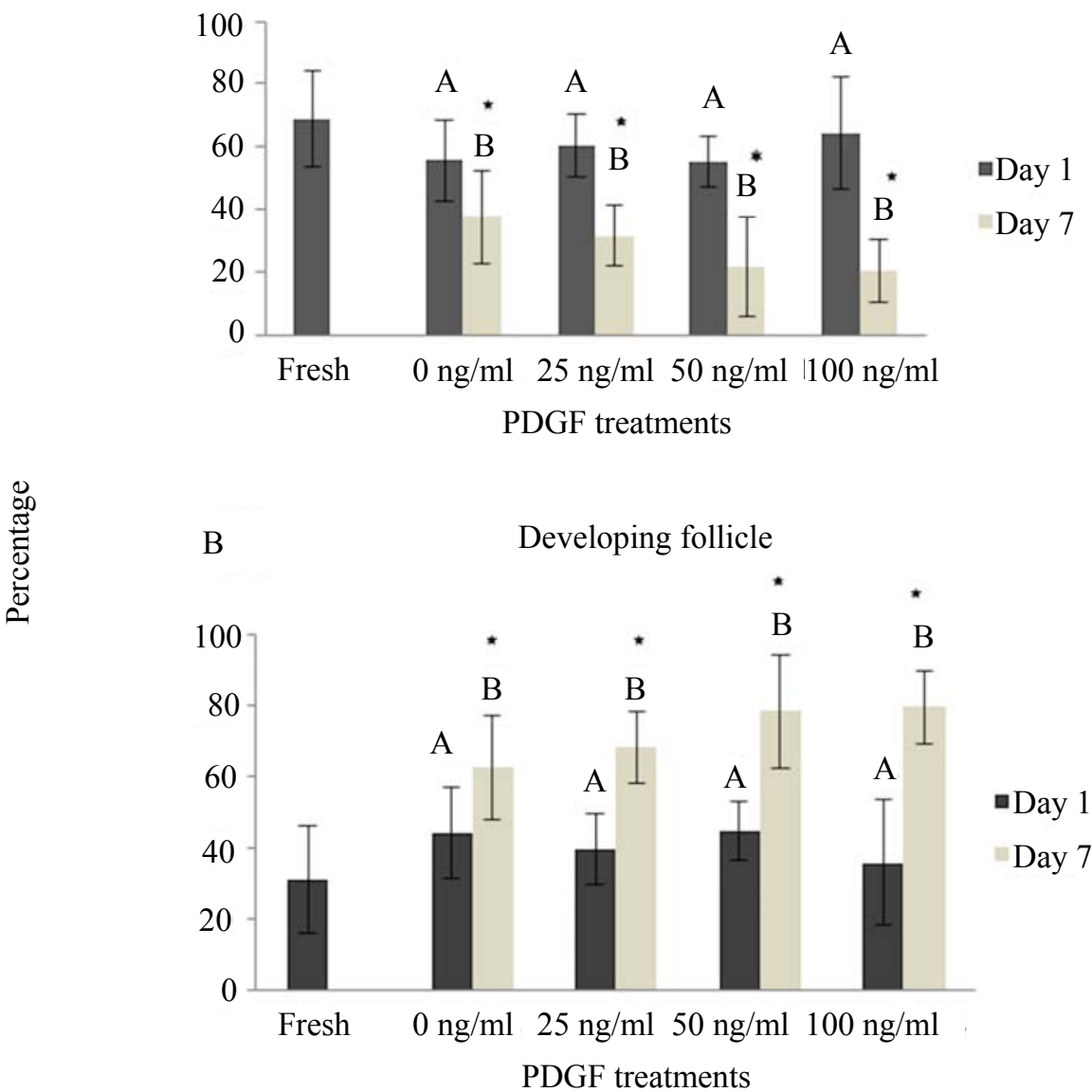

Figure 2. Percentage (mean $\pm \mathrm{SD}$ ) of $(\mathrm{A})$ primordial and $(\mathrm{B})$ growing follicles (intermediate, primary and secondary) in the fresh control (non-cultured tissue) and 1 or 7 days cultured tissue in the absence or presence of various concentrations of PDGF-BB. *Values differ significantly from fresh controls $(\mathrm{P}<0.05) .{ }^{\mathrm{AB}}$ Values with different superscripts differ between days $(\mathrm{P}<0.05)$ and among treatments within the same culture period $(\mathrm{P}>0.05)$.

Follicle and oocyte diameters were measured, and the results are shown (Table 2). After 1 day of culture for all treatments, except for the $25 \mathrm{ng} / \mathrm{ml}$ PDGF treatment, mean oocyte and follicular diameters were higher than in non-cultured control $(\mathrm{P}<0.05)$. However, after 7 days of culture no significant 
differences were observed between the treatments and non-cultured control. Overall, oocyte and follicular diameters decreased significantly from day 1 to day 7 , except for $25 \mathrm{ng} / \mathrm{ml}$ PDGF (follicle and oocyte) and 50 $\mathrm{ng} / \mathrm{ml}$ PDGF (only for follicle) treatments. In addition, at day 7 of culture, the $25 \mathrm{ng} / \mathrm{ml}$ and $50 \mathrm{ng} / \mathrm{ml}$ PDGF treatments showed similar oocyte and follicular diameters, being both higher $(\mathrm{P}<0.05)$ than $0 \mathrm{ng} / \mathrm{ml}$ PDGF alone (cultured control).

\section{Assessment of follicle viability after culture}

Follicles were classified as viable (Fig. 1C) or nonviable (Fig. 1D) if they were negatively or positively stained with trypan blue, respectively. After 7 days of culture, the percentage of viable follicles was similar between $0 \mathrm{ng} / \mathrm{ml}(68.33 \%)$ and $25 \mathrm{ng} / \mathrm{ml}(65.04 \%)$ PDGF-BB treatments, being both lower $(\mathrm{P}<0.05)$ than the non-cultured control (72.73\%) group.

\section{ROS production}

ROS production was evaluated after 1 and 7 days (Table 3 ) of culture in all tested treatments. The ROS production was not affected $(\mathrm{P}>0.05)$ neither by the treatments nor by the culture time.

Table 2. Goat oocyte and follicle diameters (mean $\pm \mathrm{SD}$ ) in the non-cultured control and 1 or 7 days cultured tissue in the absence or presence of various concentrations of PDGF-BB.

\begin{tabular}{|c|c|c|c|c|}
\hline Treatments & \multicolumn{2}{|c|}{ Follicular diameter $(\mu \mathrm{m})$} & \multicolumn{2}{|c|}{ Oocyte diameter $(\mu \mathrm{m})$} \\
\hline Control (Day 0) & \multicolumn{2}{|c|}{$24.78 \pm 7.69$} & \multicolumn{2}{|c|}{$18.94 \pm 1.39$} \\
\hline & Day 1 & Day 7 & Day 1 & Day 7 \\
\hline $0 \mathrm{ng} / \mathrm{mL}$ & $31.29 \pm 9.87^{* \mathrm{Aa}}$ & $22.21 \pm 6.48^{\mathrm{Bc}}$ & $23.30 \pm 5.84^{* A b}$ & $15.46 \pm 3.39^{\mathrm{Bc}}$ \\
\hline $25 \mathrm{ng} / \mathrm{mL}$ & $26.31 \pm 7.19^{\mathrm{Ab}}$ & $27.43 \pm 5.40^{\mathrm{Aab}}$ & $18.34 \pm 3.45^{\mathrm{Ac}}$ & $18.62 \pm 1.99^{\mathrm{Aab}}$ \\
\hline $50 \mathrm{ng} / \mathrm{mL}$ & $34.68 \pm 6.05^{* \mathrm{Aa}}$ & $30.97 \pm 9.68^{\mathrm{Aa}}$ & $26.21 \pm 4.83^{* \mathrm{Aa}}$ & $20.13 \pm 4.32^{\mathrm{Ba}}$ \\
\hline $100 \mathrm{ng} / \mathrm{mL}$ & $32.79 \pm 7.70^{* \mathrm{Aa}}$ & $24.81 \pm 5.15^{\mathrm{Bbc}}$ & $24.13 \pm 5.70^{* \mathrm{Aab}}$ & $16.08 \pm 3.19^{\mathrm{Bbc}}$ \\
\hline
\end{tabular}

*Values differ significantly from fresh non-cultured controls $(\mathrm{P}<0.05)$. ${ }^{\mathrm{AB}}$ Values with different uppercase superscript letters differ between columns (days) $(\mathrm{P}<0.05) .{ }^{\mathrm{abc}}$ Values with different lowercase superscript letters differ among rows (treatments) $(\mathrm{P}<0.05)$.

Table 3. ROS production (mean $\pm \mathrm{SD}$ ) in the 1 or 7 days cultured tissue in the absence or presence of various concentrations of PDGF-BB.

\begin{tabular}{lcc}
\hline Treatments & \multicolumn{2}{c}{ ROS production } \\
\hline $0 \mathrm{ng} / \mathrm{mL}$ & Day 1 & Day 7 \\
$25 \mathrm{ng} / \mathrm{mL}$ & $20.11 \pm 2.33$ & $22.97 \pm 1.97$ \\
$50 \mathrm{ng} / \mathrm{mL}$ & $20.38 \pm 0.90$ & $25.45 \pm 4.73$ \\
$100 \mathrm{ng} / \mathrm{mL}$ & $21.05 \pm 2.08$ & $24.41 \pm 4.20$ \\
\hline
\end{tabular}

There was no significant difference between treatments $(\mathrm{P}>0.05)$.

\section{Discussion}

The present study demonstrated for the first time the effects of PDGF-BB on the in vitro survival, activation, and growth of early caprine preantral follicles (primordial, intermediate, and primary) enclosed in ovarian tissue.

In our study, at day 7 only, we observed a higher percentage of normal follicles in the $25 \mathrm{ng} / \mathrm{ml}$ PDGF treatment than in the other treatments, including the cultured control after histological analysis. In other words, PDGF affects early goat preantral follicle survival in a concentration and culture time-dependent manner. Some studies suggest that the role of PDGF in follicular survival occurs through the PI3K pathway. Taylor (2000) showed that PDGF increased phosphatidylinositol-3-kinase (PI3-kinase) expression in a porcine theca cell cultured in vitro. Moreover, PDGF has potent mitogenic, chemotactic, and antiapoptotic effects on different cell types (Vanhaesebroeck et al., 1997). In the present study, in addition to histological analyses, a cell viability test using trypan blue was performed in order to confirm follicle survival (Paes et al., 2016). We found that despite the treatment containing $25 \mathrm{ng} / \mathrm{ml}$ PDGF having a greater follicular survival compared to the cultured control group (PDGF $0 \mathrm{ng} / \mathrm{ml}$ ), no difference was observed between these treatments after the evaluation of follicular viability when using trypan blue. This apparently contradictory result could be explained by the differences between the techniques (histology vs. viability test with trypan blue). Similar results after using the same techniques were reported in previous studies with canine (Lopes et al., 2008, 2016), equine (Haag et al., 2013) and ovine (Lunardi et al., 2012). It is known that in follicles with advanced stages of atresia, the basement membrane is discontinuous and in some cases full of holes, allowing for, as an example, the infiltration of leukocytes (Bagavant et al., 1999). Therefore, considering that atresia makes the basement membrane structure more fragile i.e., subject to rupture, the degenerate follicles detected within the ovarian tissue after histological analysis are more likely to be destroyed during the mechanical isolation of preantral follicles prior to the viability test using trypan blue and, consequently, no longer be detected by this test. As a matter of fact, follicle isolation involves a series of ovarian tissue cutting followed by the mechanical dissociation of the resulting fragments through pipetting (Lunardi et al., 2012). 
In a previous study in mice, Nilsson et al. (2006) performed a short-term culture (2 days) of mouse ovaries and found that the addition of PDGF to a base medium (D-MEM Ham's F-12) significantly increased the primordial follicle activation rate and rose the mRNA expression of kit ligand (KL) in relation to the control treatment. However, in our study using a longer culture period, after 7 days of culture, all treatments increased the percentage of developing follicles compared to the non-cultured control. In addition, regardless of the treatment, the percentage of developing follicles increased significantly from day 1 to day 7 of the culture. However, during the culture, the proportion of developing follicles was similar among the treatments, demonstrating that PDGF did not affect primordial follicle activation. These findings are in agreement with previous studies (Fortune et al., 1998; Cushman et al., 2002) that demonstrated how the activation of primordial follicles can occur spontaneously, i.e., without the addition of growth factors or hormones.

Concerning follicle and oocyte diameters, contrary to $100 \mathrm{ng} / \mathrm{ml}$ of PDGF-BB, PDGF-BB at 25 and $50 \mathrm{ng} / \mathrm{ml}$ increased both parameters as compared to $0 \mathrm{ng} / \mathrm{ml}$ PDGF alone (cultured control) after 7 days of culture. This result shows the important role of PDGF in a concentration-dependent manner on in vitro follicular and oocyte growth. Brito et al. (2012) employed a different culture system from the one used in this work (culture of isolated large secondary follicles rather than primordial follicles enclosed in ovarian tissue) and reported that the addition of $50 \mathrm{ng} / \mathrm{ml}$ PDGF, in the presence of FSH, promoted in vitro follicular growth. Furthermore, this previous work showed a higher mRNA expression of PDGF receptors in caprine developing follicles than primordial follicles, suggesting an important role in the proliferation of follicular cells (Sleer and Taylor, 2007). Lee (2000) suggested that PDGF action on cell proliferation can occur via the binding to its receptor and can be followed by the activation of PI3K and Src signaling pathways resulting in the growth and differentiation of follicular cells.

However, the higher concentration of PDGF-BB (100 ng/ml) was not able to increase follicular and oocyte diameters. In fact, a previous study demonstrated that an overstimulation of PDGF-BB receptors makes insensible the PI3K or other pathways, jeopardizing the oocyte growth (Liu et al., 2014). In our study, we found that of regardless the PDGF-BB concentration used, ROS production was similar to the cultured control. This data shows that the best follicular survival rates observed in the presence of $25 \mathrm{ng} / \mathrm{ml}$ of PDGF, compared to the cultured control, were not associated with a reduced production of ROS. This fact indicates that the ROS levels were adequate for the functioning of cultured preantral follicles. Production of ROS has been used to assess in vitro oocyte quality (Ou et al., 2012; Martinho et al., 2014), and the balance between the production and degradation of ROS is an indicator of oxidative regulation (Rizzo et al., 2012; Winterbourn, 2014).

Previous studies have shown that ROS can act as second messengers and that adequate levels play an essential physiological and biochemical role, stimulating cell proliferation and differentiation (Talebi et al., 2012). However, in contrast to our study, Rigacci et al. (1997) found that the PDGF addition to the culture medium (D-MEM) increased glutathione and hydrogen peroxide levels in response to PDGF receptor activation in murine fibroblasts, contributing to the reduction of ROS levels. A possible reason for these differences might be the different cell types (ovarian tissue vs. fibroblasts) and culture conditions $\left(5 \% \mathrm{CO}_{2} / 39^{\circ} \mathrm{C}\right.$ using $\alpha$-MEM vs. $8 \% \mathrm{CO}_{2} / 7^{\circ} \mathrm{C}$ using D-MEM).

In conclusion, PDGF-BB improved, in a concentration-dependent manner, follicular survival as well as oocyte and follicular diameter after in vitro culture of goat preantral follicles enclosed in ovarian tissue fragments.

\section{Acknowledgments}

This work was supported by this study was sponsored by Conselho Nacional de Desenvolvimento Científico e Tecnológico (CNPq grant number 407594/2013-2). R.F. Silva was supported by a Coordenação de Aperfeiçoamento de Pessoal de Nível Superior (CAPES) Fellowship.

\section{References}

Aguiar FLN, Lunardi FO, Lima LF, Rocha RMP, Bruno JB, Magalhães-Padilha DM, Cibin FWS, Nunes-Pinheiro DCS, Gastal MO, Rodrigues APR, Apgar GA, Gastal EL, Figueiredo JR. 2016a. FSH supplementation to culture medium is beneficial for activation and survival of preantral follicles enclosed in equine ovarian tissue. Theriogenology, 85:1106-1112.

Aguiar FLN, Lunardi FO, Lima LF, Rocha RMP, Bruno JB, Magalhães-Padilha DM, Cibin FWS, Rodrigues APR, Gastal MO, Gastal EL, Figueiredo JR. 2016b. Insulin improves in vitro survival of equine preantral follicles enclosed in ovarian tissue and reduces reactive oxygen species production after culture. Theriogenology, 85:1063-1069.

Aguiar FLN, Lunardi FO, Lima LF, Bruno JB, Alves BG, Magalhães-Padilha DM, Cibin FWS, Berioni L, Apgar GA, Lo Turco EG, Gastal EL, Figueiredo JR. 2017. Role of EGF on in situ culture of equine preantral follicles and metabolomics profile. Res Vet Sci, 115:155-164.

Bagavant H, Adams S, Terranova P, Chang A, Kraemer FW, Lou Y, Kasai K, Luo AM, Tung KSK. 1999. Autoimmune ovarian inflammation triggered by Proinflammatory (Th1) $\mathrm{T}$ cells is compatible with normal ovarian function in mice. Biol Reprod, 61:635642.

Berridge MJ. 1993. Inositol triphosphate and calcium signalling. Nature, 361:315-332.

Brito IR, Lima IMT, Saraiva MVA, Silva CMG, Magalhães-Padilha DM, Araújo VR, Barreto Luz V, Barbalho Silva AW, Campello CC, Silva JRV, Figueiredo JR. 2012. Expression levels of mRNAencoding PDGF receptors in goat ovaries and the 
influence of PDGF on the in vitro development of caprine pre-antral follicles. Reprod Domest Anim, 47:695-703.

Brito IR, Silva CMG, Duarte ABG, Lima IMT, Rodrigues GQ, Rossetto R, Sales AD, Lobo CH, Bernuci MP, Rosa-e-Silva ACJS, Campello CC, Xu M, Figueiredo JR. 2014. Alginate hydrogel matrix stiffness influences the in vitro development of caprine preantral follicles. Mol Reprod Dev, 81:636-645.

Brito IR, Sales AD, Rodrigues GQ, Lobo CH, Castro SV, Silva AWB, Moura AAA, Silva JRV, Rodrigues APR, Figueiredo JR. 2015. Differential gene expression and immunolocalization of platelet-derived growth factors and their receptors in caprine ovaries. Domest Anim Endocrinol, 51:46-55.

Bruno JB, Celestino JJ, Lima-Verde IB, Lima LF, Matos MH, Araújo VR, Saraiva MV, Martins FS, Campello CC, Figueiredo JR. 2009. Expression of vascular endothelial growth factor (VEGF) receptor in goat ovaries and improvement of in vitro caprine preantral follicle survival and growth with VEGF. Reprod Fertil Dev, 21:679-687.

Carvalho AA, Faustino LR, Silva CMG, Castro SV, Lobo CH, Santos FW, Santos RR, Campello CC, Bordignon V, Figueiredo JR, Rodrigues APR. 2014. Catalase addition to vitrification solutions maintains goat ovarian preantral follicles stability. Res Vet Sci, 97:140-147.

Castro SV, Carvalho AA, Silva CMG, Santos FW, Campello CC, Figueiredo JR, Rodrigues APR. 2014. Fresh and vitrified bovine preantral follicles have different nutritional requirements during in vitro culture. Cell Tissue Bank, 15:591-601.

Chaves RN, Martins FS, Saraiva MVA, Celestino JJH, Lopes CAP, Correia JC, Lima-Verde IB, Matos MHT, Báo SN, Name KPO, Campello CC, Silva JRV, Figueiredo JR. 2008. Chilling ovarian fragments during transportation improves viability and growth of goat preantral follicles cultured in vitro. Reprod Fertil Dev, 20:640-647.

Chaves RN, Alves AMCV, Duarte ABG, Araújo VR, Celestino JJH, Matos MHT, Lopes CAP, Campello CC, Name KPO, Báo SN, Figueiredo JR. 2010. Nerve growth factor promotes the survival of goat preantral follicles cultured in vitro. Cells Tissues Organs, 192:272-282.

Cushman RA, Wahl CM, Fortune JE. 2002. Bovine ovarian cortical pieces grafted to chick embryonic membranes: a model for studies on the activation of primordial follicles. Hum Reprod, 174:48-54.

Duleba AJ, Spaczynski RZ, Arici A, Carbone R, Behrman HR. 1999. Proliferation and differentiation of rat theca-interstitial cells: comparison of effects induced by platelet-derived growth factor and insulin-like growth factor-I. Biol Reprod, 60:546-550.

Fortune JE, Kito SA, Wandji VS. 1998. Activation of bovine and baboon primordial follicles in vitro. Theriogenology, 49:441-449.

Fortune JE, Cushman RA, Wahl CM, Kito S. 2000. The primordial to primary follicle transition. Mol Cell Endocrinol, 163:53-60.

Fortune JE. 2003. The early stages of follicular development: activation of primordial follicles and growth of preantral follicles. Anim Reprod Sci, 78:135163.

Gaultier CJ, Michel JB. 1999. Angiogenic growth factors. In: Levy BI, Tedgui A (Ed.). Biology of the Arterial Wall. Norwell, MA: Kluwer Academic Publishers. pp. 101-111.

Haag KT, Magalhães-Padilha DM, Fonseca GR, Wischral A, Gastal MO, King SS, Jones KL, Figueiredo JR, Gastal EL. 2013. Quantification, morphology, and viability of equine preantral follicles obtained via the biopsy pick-up method. Theriogenology, 79:599-609.

Hwu YM, Li SH, Lee RK, Lin MH, Tsai YH, Yeh TS. 2009. Luteinizing hormone increases-platelet derived growth factor-D gene expression in human granulosa-luteal cells. Fertil Steril, 92:2065-2068.

Kim JY. 2012. Control of ovarian primordial follicle activation. Clin Exp Reprod Med, 39:10-14.

Lee VH. 2000. Expression of rabbit zona pellucida-1 messenger ribonucleic acid during early follicular development. Biol Reprod, 63:401-408.

Lopes CAP, Santos RR, Celestino JJH, Melo MAP, Chaves RN, Campello CC, Silva JRV, Báo SN, Jewgenow K, Figueiredo JR. 2008. Short-term preservation of canine preantral follicles: effects of temperature, medium and time. Anim Reprod Sci, 115:201-214.

Lopes CAP, Alves AMCV, Jewgenow K, Báo SN, Figueiredo JR. 2016. Cryopreservation of canine ovarian cortex using DMSO or 1,3-propanediol. Theriogenology, 86:1165-1174.

Liu X. 2014. Overstimulation can create health problems due to increases in PI3K/Akt/GSK3 insensitivity and GSK3 activity. Springerplus, 3:356368.

Loetchutinat C, Kothan S, Dechsupa S, Meesungnoen J, Jay-Gerin JP, Mankhetkorn S. 2005. Spectrofluorometric determination of intracellular levels of reactive oxygen species in drug-sensitive and drugresistant cancer cells using the 2',7'dichlorofluorescein diacetate assay. Radiat Phys Chem, 72:323-331.

Lucci CM, Amorim CA, Báo SN, Figueiredo JR, Rodrigues APR, Silva JRV, Gonçalves PBD. 1999. Effect of the interval of serial sections of ovarian tissue in the tissue chopper on the number of isolated caprine preantral follicles. Anim Reprod Sci, 56:39-49.

Lunardi FO, Araújo VR, Faustino LR, Carvalho AA, Gonçalves RFB, Bass CS, Báo SN, Name KPO, Campello CC, Figueiredo JR, Rodrigues APR. 2012. Morphologic, viability and ultrastructural analysis of vitrified sheep preantral follicles enclosed in ovarian tissue. Small Rumin Res, 107:121-130.

Magalhães-Padilha DM, Geisler-Lee J, Wischral A, Gastal MO, Fonseca GR, Eloy YRG, Geisler M, Figueiredo JR, Gastal EL. 2013. Gene expression during early folliculogenesis in goats using microarray analysis. Biol Reprod, 89:19. doi: 10.1095/biolreprod.112.106096.

Martinho NA, Dell'Aquila ME, Uranio MF, Rutigliano L, Nicassio M, Lacalandra GM, Hinrichs 
K. 2014. Effect of holding equine oocytes in meiosis inhibitor-free medium before in vitro maturation and of holding temperature on meiotic suppression and mitochondrial energy/redox potential. Reprod Biol Endocrinol, 12:99. doi: 10.1186/1477-7827-12-99.

McLaughlin EA, McIver SC. 2008. Awakening the oocyte: controlling primordial follicle development. Reproduction, 137:1-11. doi: 10.1530/REP-08-0118.

Nilsson EE, Detzel C, Skinner MK. 2006. Plateletderived growth factor modulates the primordial to primary follicle transition. Reproduction, 131:10071015.

Oktem O, Oktay K. 2008. The ovary: anatomy and function throughout human life. Sciences (New York), 1127:1-9. doi: 10.1196/annals.1434.009.

Ou XH, Li S, Wang ZB, Li M, Quan S, Xing F, Guo L, Chao SB, Chen Z, Liang XW, Hou Y, Schatten H, Sun QY. 2012. Maternal insulin resistance causes oxidative stress and mitochondrial dysfunction in mouse oocytes. Hum Reprod, 27:2130-2145.

Paes VM, Vieira LA, Correia HHV, Sa NAR, Moura AAA, Sales AD, Rodrigues APR, Magalhães-Padilha DM, Santos FW, Apgar GA, Campello CC, Camargo LSA, Figueiredo JR. 2016. Effect of heat stress on the survival and development of in vitro cultured bovine preantral follicles and on in vitro maturation of cumulus-oocyte complex. Theriogenology, 86:9941003.

Rigacci S, Iantomasi T, Marraccini P, Berti A, Vincenzini MT, Ramponi G. 1997. Evidence for glutathione involvement in platelet-derived growthfactor mediated signal transduction. Biochem $J$, 324:791-796.

Rizzo A, Roscino MT, Binetti F, Sciorsci RL. 2012. Roles of reactive oxygen species in female reproduction. Reprod Domest Anim, 47:344-352.

Rubin K, Tingstro AM, Hansson GK, Larsson E, Nnstrand L, Klareskog L, Claesson-Welsh L, Heldin CH, Fellstro BM, Terracio L. 1988. Induction of Btype receptors for platelet-derived growth factor in vascular inflammation: possible implications for development of vascular proliferative lesions. Lancet, 1:1353-1356.
Sá NAR, Araújo VR, Correia HHV, Ferreira ACA, Guerreiro DD, Sampaio AM, Escobar E, Santos FW, Moura AA, Lôbo CH, Ceccatto VM, Campello CC, Rodrigues APR, Leal-Cardoso JH, Figueiredo JR. 2017. Anethole improves the in vitro development of isolated caprine secondary follicles. Theriogenology, 89:226-234.

Silva JRV, Van Den Hurk R., Matos MHT, Santos RR, Pessoa C, Moraes MO, Figueiredo JR. 2004. Influences of FSH and EGF on primordial follicles during in vitro culture of caprine ovarian cortical tissue. Theriogenology, 61:1691-1704.

Sleer LS, Taylor CC. 2007. Cell-type localization of platelet-derived growth factors and receptors in the postnatal rat ovary and follicle. Biol Reprod, 76:379390.

Talebi A, Zavareh S, Kashani MH, Lashgarbluki T, Karimi I. 2012. The effect of alpha lipoic acid on the developmental competence of mouse isolated preantral follicles. J Assist Reprod Genet, 29:175-183.

Taylor CC. 2000. Platelet-derived growth factor activates porcine thecal cellphosphatidylinositol-3kinase-Akt/PKB and ras-extracellular signal-regulated kinase-1/2 kinase signaling pathways via the plateletderived growth factor-beta receptor. Endocrinology, 141:1545-1553.

Van Den Hurk R, Zhao J. 2005. Formation of mammalian oocytes and their growth, differentiation and maturation within ovarian follicles. Theriogenology, 63:1717-1751

Vanhaesebroeck B, Leevers SJ, Panayotou G, Waterfield MD. 1997. Phosphoinositide 3-kinases: a conserved family of signal transducers. Trends Biochem Sci, 7:267-272.

Winterbourn CC. 2014. The challenges of using fluorescent probes to detect and quantify specific reactive oxygen species in living cells. Biochim Biophys Acta, 1840:730-738.

Young RM, Mendonza AE, Collins T, Orkin SH. 1990. Alternatively spliced platelet-derived growth factor A-chain transcripts are not tumor specific but encode normal cellular proteins. Mol Cell Biol, 11:6051-6054. 